melting points of his metals and the need for an ordered sequence in his alloying procedures, and he made use of pitch or bitumen where we should today use charcoal for a cover in melting.

The general impression one receives is of an experienced master goldsmith serving his richer customers with genuine gold jewellery and his more impecunious clients-including probably the tourists who even then came to visit Thebes from other parts of the Roman Empire-with imitation jewellery made from silver or from base metal alloys with or without gilding.

The papyrus, then, is the oldest text we have giving practical directions for refining, alloying and other metallurgical operations. It was written at about the time that the Emperor Constantine was establishing Byzantium as the new capital of the Roman Empire and summoning the first Council of Churches at Nicaea. It is in fact almost exactly as old as the earliest and beautifully produced complete copies of the Bible, made at Constantine's own command to the Bishop of Caesarea for use in Constantinople, such as the famous Codex Sinaiticus now preserved in the British Museum.

\section{Acknowledgements}

The writer wishes to thank Mr T. G. H. James, Keeper of the Department of Egyptian Antiquities at the British Museum, and Dr E. G. Turner, Professor of Papyrology at University College, London, for their help and advice in the preparation of this paper.

\section{References}

1 C. Leemans, "Papyri Graeci Musei Antiquarii Publici Lugduni Batavi", Leyden, 1885, pp. 209-249

$2 \mathrm{M}$. Berthelot and C. E. Rouelle, "Collection des Anciens Alchemistes Grecs", Paris, 1887, Vol. I, pp. 19-73

3 E. O. von Lippmann, "Chemische Papyri des 3 Jahrhunderts", Chem. Zeit., 1913, 37, 933-934, 962$964,1002-1004$, and 1014-1015

4 E. R. Caley, "The Leyden Papyrus X", f. Chem. Ed., 1926, 3, 1149-1166

5 M. Berthelot and C. E. Rouelle, op. cit., p. 70

6 See R. T. Gunther, "The Greek Herbal of Dioscorides", New York, 1934

7 E. J. Holmyard, "Alchemy", London, 1957, p. 25

8 I. Hammer-Jensen, 'Deux Papyrus a Contenu D'Ordre Chimique", Oversigt over det. Kgl. Danske Videnskabernes Selskabs Forhandlinger, 1916, (4), 279-302

9 Uvo Hölscher, "The Excavation of Medinet Habu, Vol. V, Post-Romanised Remains", Chicago, 1954

10 R. Halleux, Chronique d'Egypt, 1973, 48, 370-380

11 Pliny, Historia Naturalis, XXXIII, 25

12 J. B. Boussingault, Ann. Chim. Phys., 1833, 54, 253-263

13 J. H. F. Notton, "Ancient Egyptian Gold Refining" Gold Bull., 1974, 7, 50-56

14. M. Levy, "Chemistry and Chemical Technology in Ancient Mesopotamia", London, 1959, p. 188-189

15 P. M. Roberts, "Gold Brazing in Antiquity", Gold Bull., 1973, 6, 112-119

$16 \mathrm{~S}$. Alexander, "Notes on the Use of Gold Leaf in Egyptian Papyri", F. Egypt. Archaeology, 1965, 51, $48-52$

17 "Suidas Lexicon", Ed. Ada Adler, Leipzig, 1931, Vol. II, p. 104

18 Edward Gibbon, "The Decline and Fall of the Roman Empire", London, 1776 and many later editions. See Vol. I under the year 297 A.D.

19 For Theophilus on gold see C. R. Dodwell, "Gold Metallurgy in the Twelfth Century", Gold Bull., 1971, 4, 51-55

\title{
The First Gold Plating in America
}

The major part played by George Richards Elkington of Birmingham in taking the first practical steps towards the commercial development of gold plating is well known and has been described in an earlier issue of this journal (Gold Bulletin, 1973, 6, (1), 16-27). In September 1840 , together with his cousin Henry and the surgeon John Wright, he had filed a patent on the use of cyanide baths and, a year or two later, having failed in his attempts to license other manufacturers to use his process, he was about to establish his leading position in England as a gold and silver plater.

Unfortunately for him, Elkington did not file this patent in the United States, so leaving the field open to anyone to take advantage of his disclosure. Such an initiative was taken with astonishing alacrity-if not perhaps with too high a regard for the truth-by one Sumner Smith, a native of Brighton, Massachusetts, who had settled in Hartford, Connecticutt, where he was employed as a watch-maker and repairer by the jeweller Horace Goodwin.

Sumner Smith was also in practice as a patent agent, while he is further on record as being a member of the Franklin Institute. The journal published by this body, The fournal of the Franklin Institute and Mechanics' Register, contained from time to time short articles taken from the London and other trade and technical journals, and in the years 1840 to 1842 it included a number of references to the earlier Elkington patents

\section{GALVANISM.}

7 NEE subscriber would respectfully announce to the public that he has discovered the art of Gilding, Silvering, \&c., by Galvanism; all orders len at the store of HORACE GoOdwin, 2d, 166 Main street, will be promptly attended to. The superiority of this process consists in the fact, that any quantity of gold or silver can be pot on to all kinds of metals, and will stand the tesi of acids or alkalies ; the superiority of the articles thus covered, will be seen at a glance.

N. B. Any person wishing information in this beautiful $A r t$, can obtain it of the subscriber for a moderate compensation.

nov 1

SUMNER SMITH. $6 \mathrm{~d} 50$

on immersion gilding as well as to the work of De la Rive in Geneva on gold plating. There is, however, no reference during this period to the final Elkington patent that was vital to the successful electrodeposition of gold. Possibly, as a patent agent, Smith was in correspondence with a fellow agent in London, but by whatever means he obtained the information-and no doubt his interest was aroused by the earlier disclosures - he was moved to insert in the Hartford Times in November 1842 the advertisement reproduced here.

I.B.H. 